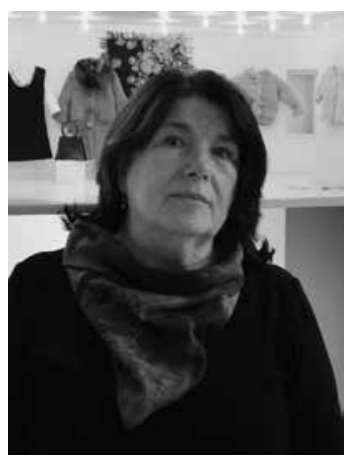

\title{
DAILININKĖ JŪRATĖ PETRUŠKEVIČIENĖ
}

Dailininkẻ JŪRATÉ PETRUŠKEVIČIENÉ gimė 1949 m. vasario 2 d. Kaune. Mokyklą baigè 1966 m., o 1967 m. istojo ì Vilniaus dailès instituto Kauno taikomosios dailès skyrių studijuoti tekstilès. Baigusi šią specialybę 1973 m. ji pradèjo dirbti Kauno „Dailès“ kombinate. Čia ji perprato įvairius tekstilès gaminių techninio apdorojimo būdus, buvo mažatiražès gamybos dailininkè, kūrẻ interjerui skirtus monumentalius tekstilès darbus. Tuo metu ji pradèjo dalyvauti ịvairiose Kauno „Dailès" kombinato surengtose parodose Lietuvoje ir užsienyje, rengè ir personalines unikalių kūrinių parodas, buvo įvairių grupinių projektų dalyvè. Parodu gyvenime menininkė itin aktyviai dalyvauja iki šiol: būtų sunku išvardyti visas šalis, muziejus ir renginius, kur buvo eksponuoti menininkès darbai. Tai ne tik įspūdingi pasirodymai Europos muziejuose (Prancūzijoje, Latvijoje, Lenkijoje, Belgijoje, Vokietijoje, Vengrijoje, Italijoje, Suomijoje ir kt.), bet ir parodos itin tolimose šalyse - JAV, Japonijoje, Australijoje.

Dirbdama ir kurdama Petruškevičienè visuomet ilgèjosi pedagoginès veiklos. Atrodo, tai igimtas polinkis, nes dailininkès tèvai ir seneliai taip pat buvo pedagogai. Tad 1990 m. ji ėmé dirbti Kauno "Aušros" gimnazijoje vaizduojamosios dailès klasėse pavaduotoja, o nuo $1991 \mathrm{~m}$. tapo Vilniaus dailès akademijos Kauno fakulteto Tekstilès katedros dėstytoja. Čia iki šiol eina docentės pareigas. Menininkè dèsto spalvotyrą, ivvairias tekstilès technologijas, vadovauja studentų baigiamiesiems diplominiams darbams.

Doc. dr. Raimonda Simanaitienè Vytauto Didžiojo universitetas

\section{Artist Jūratė Petruškevičienè}

Artist JŪRATÉ PETRUŠKEVIČIENÉ was born on February 2nd, 1949 in Kaunas. She graduated school in 1966, and in 1967 entered Vilnius Art Institute, Kaunas Applied Art department to study textile. After graduating in 1973 she started working in Kaunas "Art" Combine. Here, the artist mastered various techniques of textile manufacture and produced both small edition works and monumental textile objects, dedicated to interiors. Already at this period, she started her participation in Kaunas "Art" Combine exhibitions in Lithuania and in countries abroad. She organized personal expositions of unique works and partook in various group projects. The artist is still actively participating in exhibitions. It would be difficult to name all the countries, museums and events in which the works of Jūrate Petruškevičienè have been exhibited. 
The range of her magnificent appearances goes from museums in Europe (France, Latvia, Poland, Belgium, Germany, Hungary, Italy, Finland and other) to the more distant countries - USA, Japan, and Australia.

While working and creating, Petruškevičienė has always longed for pedagogical activities. This seemed to be an innate tendency, for her parents and grandparents were educators. For this reason in 1990 she started working in Kaunas "Aušros" Gymnasium as a substitute teacher for visual art classes. From 1991 she also commenced lecturing in Vilnius Art Academy, Kaunas Faculty Textile Department, where she is still working in a docent position. Here she teaches color analysis, various textile technologies, and curates graduation works of students.

Assoc. Prof. Dr. Raimonda Simanaitienè, Vytautas Magnus University

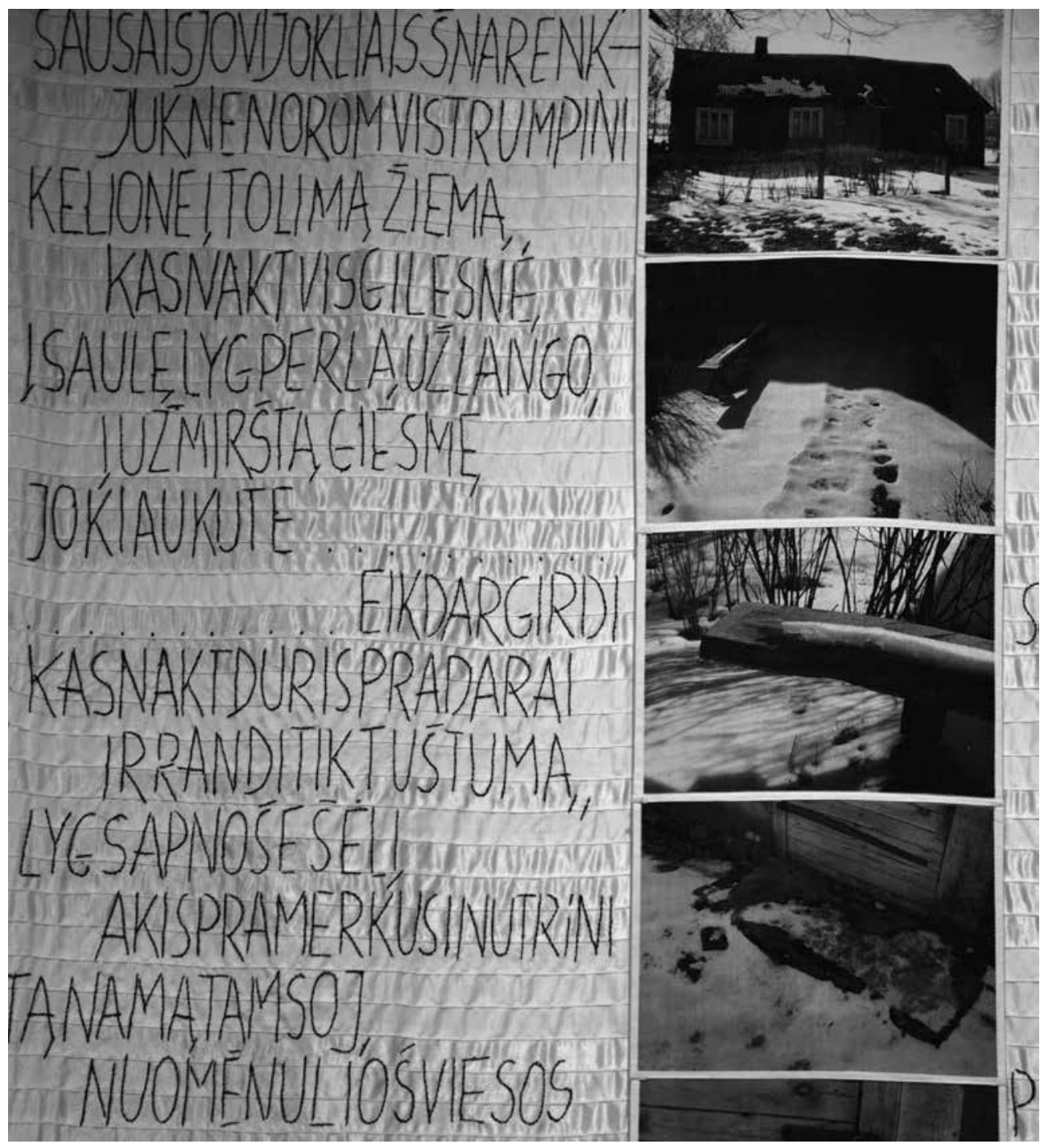

J. PETRUŠKEVIČIENĖ. Namas tamsoje - Bronei, 2005. Fragmentas. Kaprono kaspinai, siuvimas, siuvinėjimas, foto ant audinio, $280 \times 130$ 


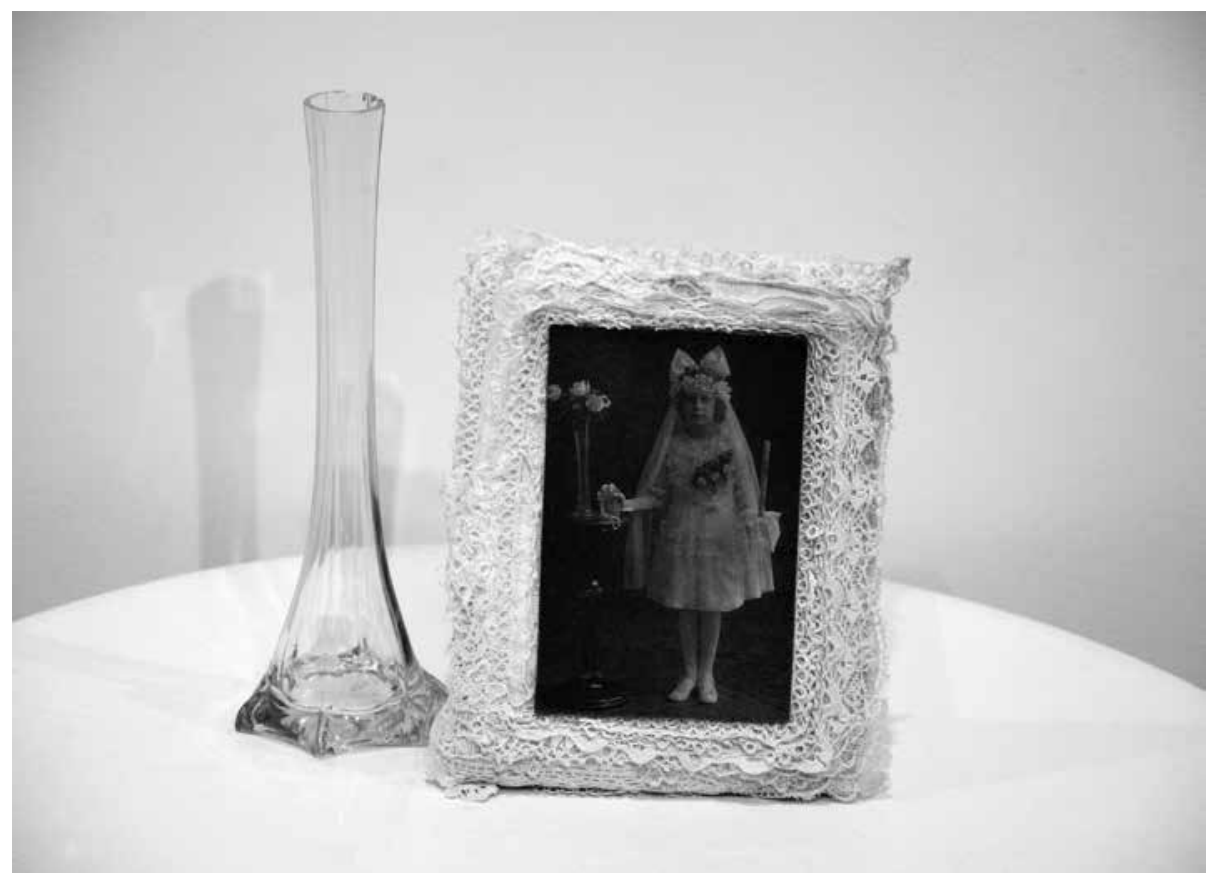

J. PETRUŠKEVIČIENĖ. Baltoji diena, 2002. Mezginiai, medvilnė, foto ant audinio, siuvimas, vazelè $(25 \mathrm{~cm}), 21 \times 16$

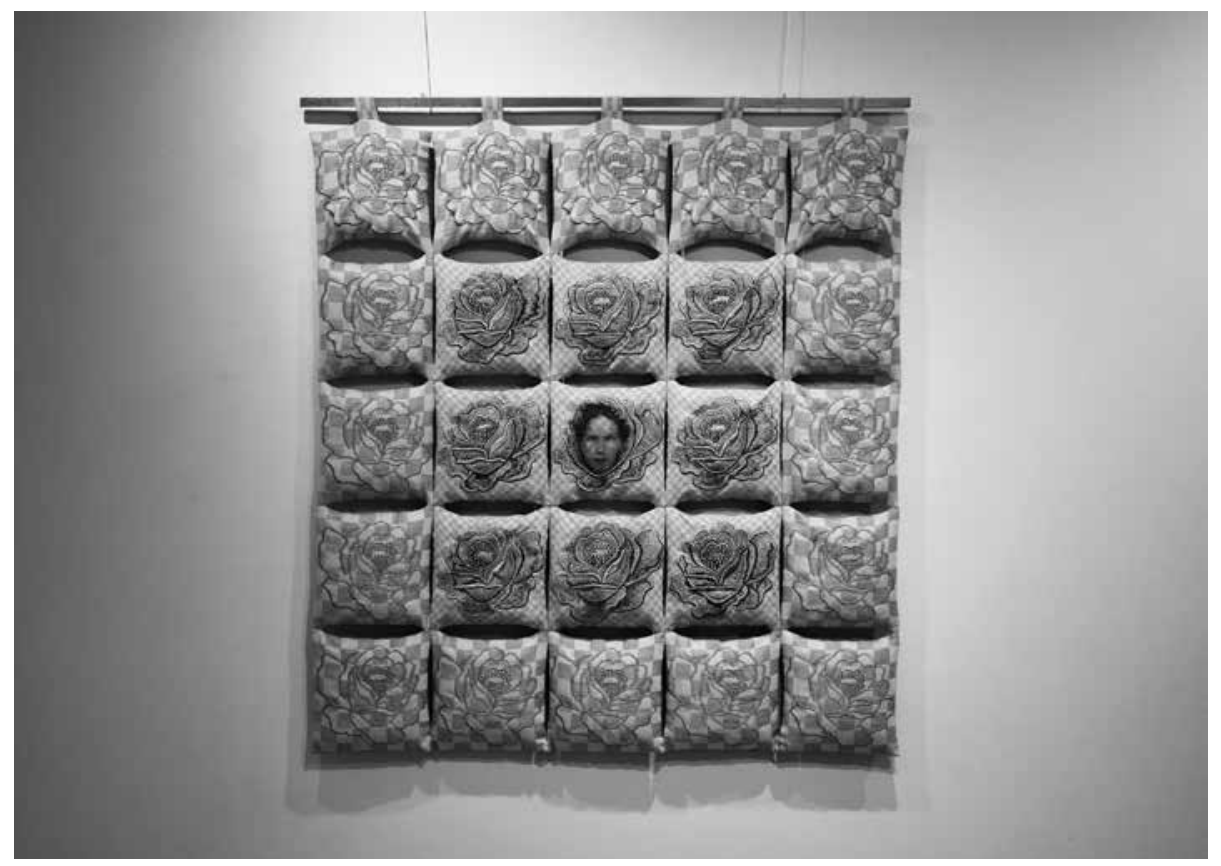

J. PETRUŠKEVIČIENĖ. Nepažintai močiutei Grasildai, 2003. Linas, metalizuoti siūlai, foto ant audinio, siuvinèjimas mašina ir rankomis, $118 \times 114 \times 4$ 


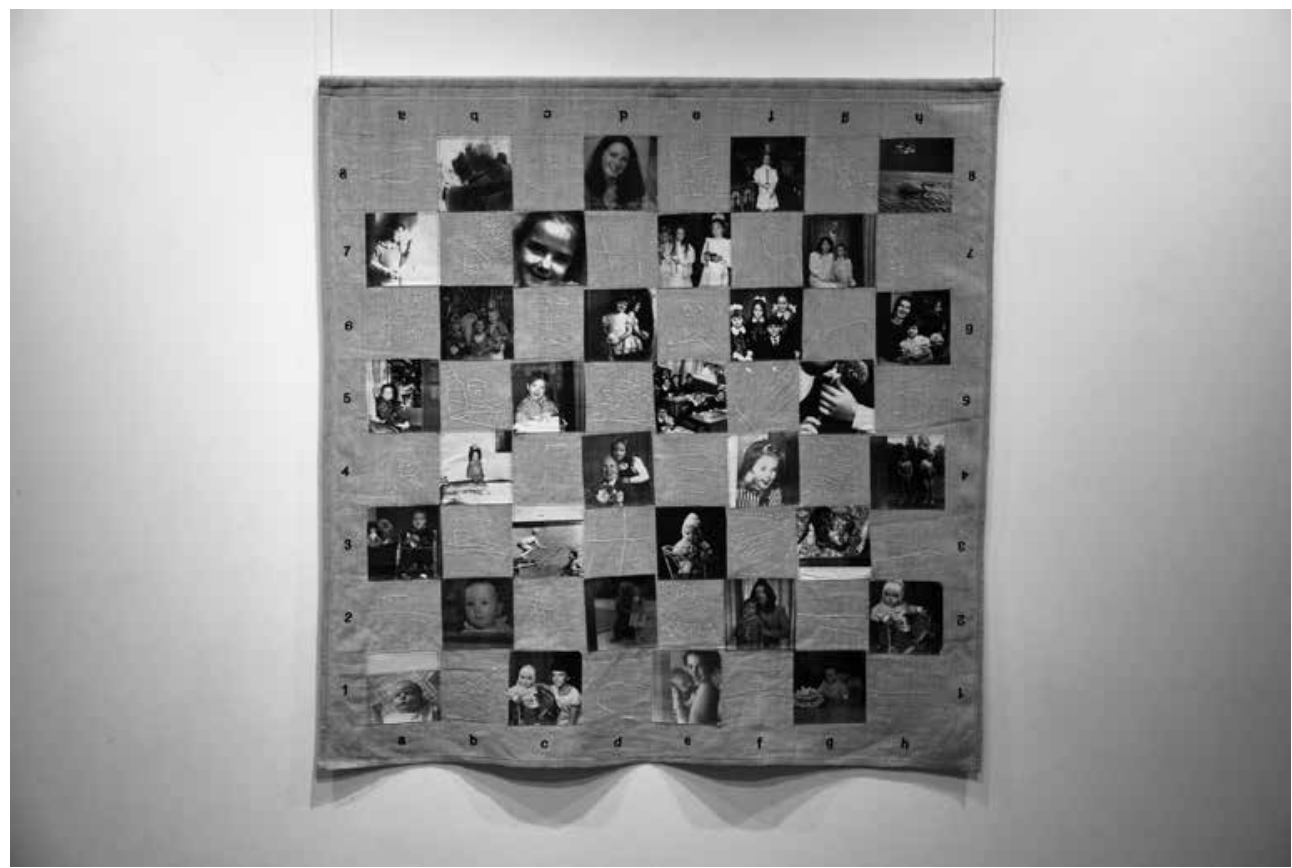

J. PETRUŠKEVIČIENĖ. Žaidimas su laiku, 2003. Linas, foto ant audinio, siuvinèjimas mašina, $100 \times 100$

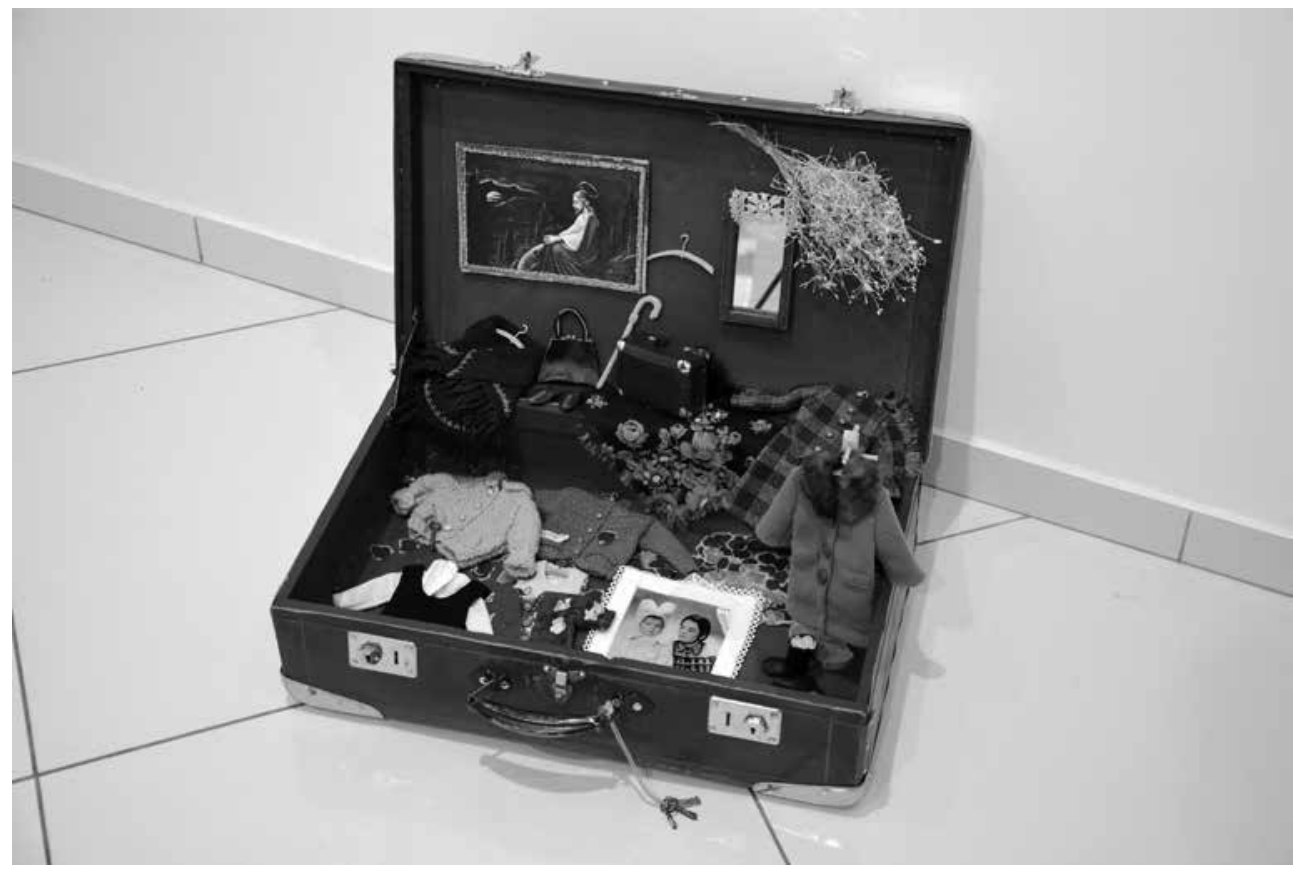

J. PETRUŠKEVIČIENĖ. Emilijos pasaulis, 2011. Siūlai, oda, medis, siuvimas, mezgimas, siuvinėjimas, drožimas, klijavimas, 22 mini darbai iki $18 \mathrm{~cm}$ aukščio 


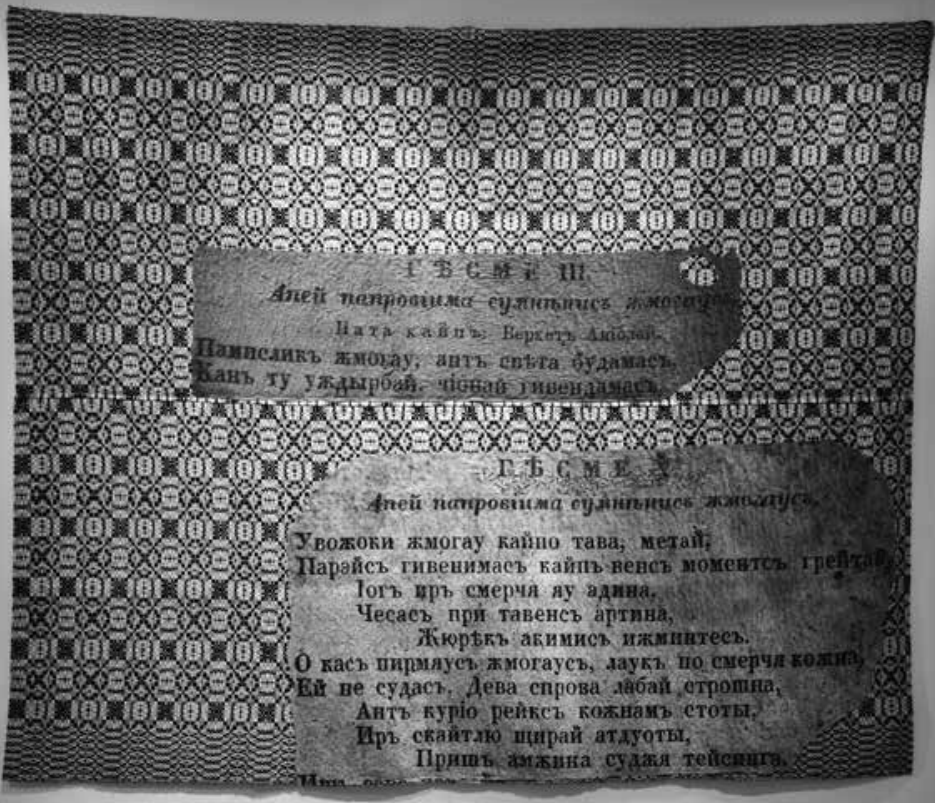

J. PETRUŠKEVIČIENĖ. Lietuviškos spaudos draudimas (graždanka), 2010. Sena lovatiesė, poliesteris, skaitmeninè spauda, siuvinëjimas, aplikacija, $145 \times 180$

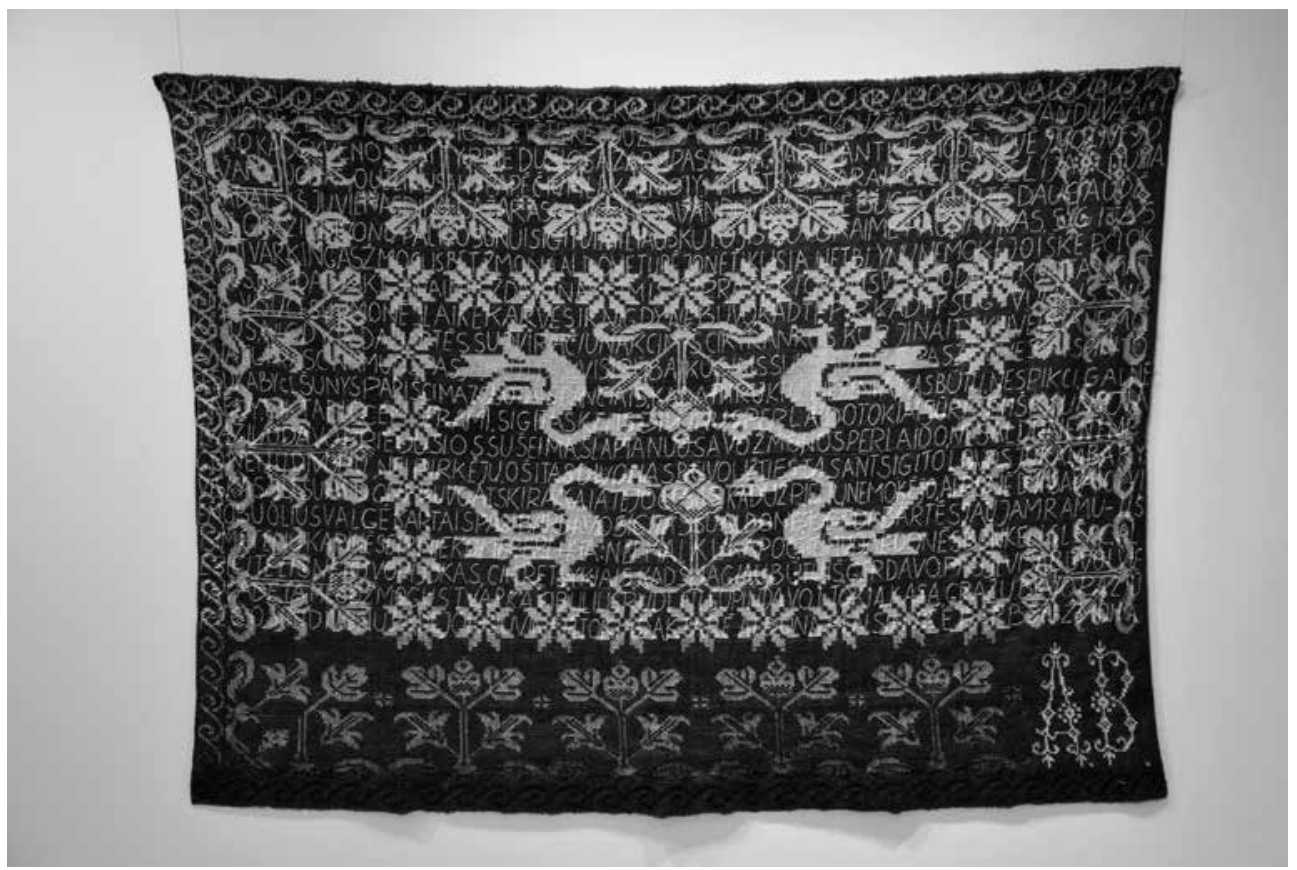

J. PETRUŠKEVIČIENĖ. Dzūkiška istorija, 2013. Sena lovatiesė, metalizuoti siūlai, siuvinèjimas, $140 \times 190$ 


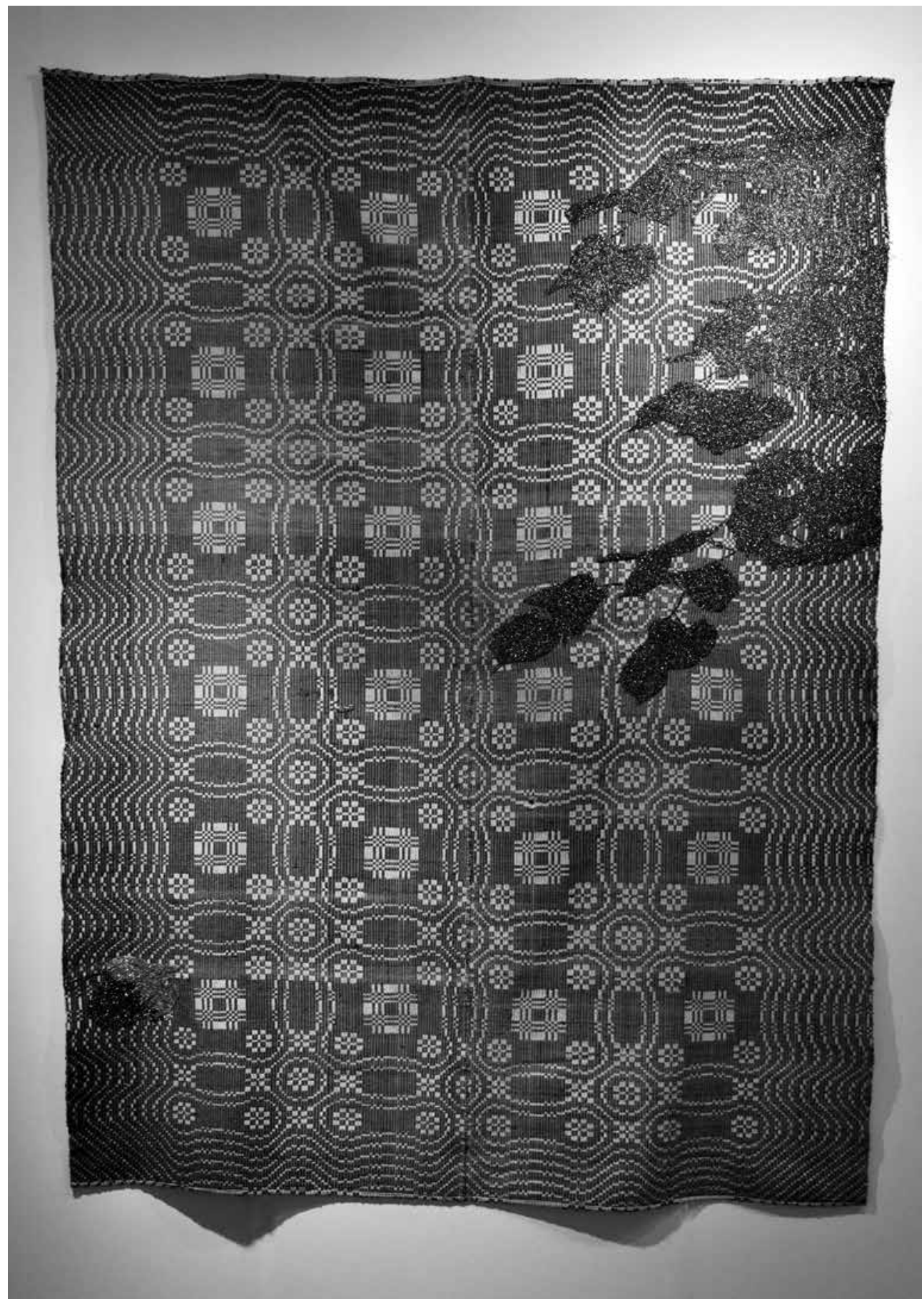

J. PETRUŠKEVIČIENĖ. Saulès šviesa, 2010. Sena lovatiesė, metalizuoti siūlai, siuvinëjimas, $186 \times 136$ 